\title{
Biological treatment of drippers clogged by the use of treated domestic wastewater
}

\author{
Danniely O. Costa ${ }^{1}$, Rafael O. Batista ${ }^{1}$, Hudson S. M. Vale ${ }^{1}$, \\ Amanda B. de Sousa ${ }^{1}$, Solange A. G. Dombroski ${ }^{1}$ \& Sandra M. C. Alves ${ }^{1}$
${ }^{1}$ Universidade Federal Rural do Semi-Árido/Departamento de Ciências Ambientais e Tecnológicas. Mossoró, RN. E-mail: danniely_oliveira@hotmail.com; rafaelbatista@ufersa.edu.br (Corresponding author); klaus_angel@hotmail.com; amandabez12@yahoo.com.br; solangedombroski@ufersa.edu.br; sandraalves@ufersa.edu.br

\section{Key words:}

emitters

wastewater

unclogging

bacteria

\begin{abstract}
A B S T R A C T
This study aimed to recover the flow rate of clogged drippers with different doses and permanence times of the product MaxBio. The experiment was conducted in a completely randomized design in split-split-plot scheme, where the plots corresponded to product doses $\left(80,160,240\right.$ and $\left.320 \mathrm{mg} \mathrm{L}^{-1}\right)$, subplots to the applied treatments (T1 - without biological treatment, T2 $-1^{\text {st }}$ application of the product, and T3 $-2^{\text {nd }}$ application of the product) and in sub-subplots the types of emitters (Plastro Hydrodrip Super, Netafim Tiran and Netafim PCJ-CNJ), with three replicates. The four irrigation units operated with treated domestic wastewater for $400 \mathrm{~h}$ in order to clog the emitters. After applying the product MaxBio, the flow rate of the drippers and the relative flow rate reduction were determined to express the unclogging levels. There was significant effect of T2 and T3 on the recovery of the flow rate of the drippers, while for the reduction of relative flow rate, the doses of the product did not show statistical difference regarding the types of drippers.
\end{abstract}

\section{Palavras-chave:}

emissores

água residuária

desentupimento

bactérias

\section{Tratamento biológico de gotejadores obstruídos pelo uso de efluente doméstico tratado}

\begin{abstract}
R E S U M O
Objetivou-se, neste trabalho, recuperar a vazão de gotejadores obstruídos com diferentes dosagens e tempos de permanência do produto MaxBio. O experimento foi montado no delineamento inteiramente casualizado em esquema de parcelas subsubdivididas tendo, nas parcelas, as doses do produto $\left(80,160,240\right.$ e $\left.320 \mathrm{mg} \mathrm{L}^{-1}\right)$, nas subparcelas, os tratamentos aplicados (T1 - sem tratamento biológico; T2 - $1^{\mathrm{a}}$ aplicação do produto e T3 - 2a aplicação do produto) e, nas subsubparcelas, os tipos de gotejadores (Plastro Hydrodrip Super, Netafim Tiran e Netafim PCJ-CNJ), em três repetições. As quatro unidades de irrigação operaram com água residuária doméstica tratada, durante $400 \mathrm{~h}$ proporcionando a obstrução dos gotejadores. Após aplicação do produto MaxBio a vazão dos gotejadores e a redução da vazão relativa foram determinadas para expressar os níveis de desobstrução. Na recuperação da vazão dos gotejadores houve efeito significativo dos tratamentos T2 e T3 enquanto para a redução da vazão relativa às doses do produto não apresentaram diferença estatística em relação aos tipos de gotejadores.
\end{abstract}




\section{INTRODUCTION}

The use of wastewater in agriculture is an alternative for the control of environmental pollution, besides providing water and nutrients to crops (Batista et al., 2011), thus being of great importance in the semi-arid region due to the relief in the demand and preservation in the supply of water for multiple purposes (Hespanhol, 2009).

Among the methods of irrigation, from the environmental perspective, localized irrigation is the most recommended for the disposal of wastewater in the environment, because of the high efficiency of application of the effluent and low risk of contamination of the agricultural product and the operators at the field (Souza et al., 2011; Rowan et al., 2013). However, drip irrigation systems show high susceptibility to emitter clogging (Liu \& Huang, 2009; Li et al., 2011; 2012) when wastewater is applied (Dazhuang et al., 2009; Yan et al., 2009; 2010; Batista et al., 2013).

The most used practices for unclogging the drippers include chemical treatment, using chlorination and acidification (Batista et al., 2012), increase in operating pressure (Silva et al., 2013), washing of lateral lines (Puig-Bargues et al., 2010) and biological treatment (Şahin et al., 2005; Eroglu et al., 2012).

The biological treatment of drippers, unlike the use of inorganic chlorinated derivatives, has been highlighted due to the non-generation of carcinogenic substances, besides the biological control of microorganisms pathogenic to plants (Şahin et al., 2005).

Based on the above, this study aimed to evaluate the efficiency of biological treatment through different doses and permanence times of the product MaxBio with Byosol Swift, in the recovery of the flow rate of emitters clogged by the use of treated domestic wastewater.

\section{Material ANd Methods}

This study was carried out from March 18 to May 14, 2014, in the experimental area of the Federal Rural University of the
Semi-Arid (UFERSA), in Mossoró, RN, Brazil (5 12’ 27”' S; 370 19' 21" W).

The domestic wastewater was collected at the Effluent Treatment Station (ETS) administered by the company 'Imunizadora Oeste Ltda', in Mossoró, RN.

For the tests, a $4 \times 8 \mathrm{~m}$ experimental bench was built in masonry, with impermeable floor and a groove with slope of $2 \%$ for effluent recirculation. At a lower level in relation to the bench, a $5-\mathrm{m}^{3}$ tank was built in masonry to store the recirculated effluent and, beside the bench, a reservoir was built to receive the effluent transported from the ETS to the UFERSA, every 15 days. Inside the experimental bench, four drip irrigation units were mounted, which operated with effluent for $400 \mathrm{~h}$ (Figure 1).

The bench consisted of one 1-hp motor pump set, one 130$\mu \mathrm{m}$ screen filter, one hydrometer of $1.5 \mathrm{~m}^{3} \mathrm{~h}^{-1}$ and one injection system for the biological treatment of the drippers (composed of a 0.5 -hp motor pump and one 62-L container to store the solution with bacteria).

Each irrigation unit had a gate valve and one analog glycerine manometer graduated from 0 to $400 \mathrm{kPa}$, for pressure regulation, and one derivation line (PVC, $32 \mathrm{~mm}$ ) with nine connectors for the insertion of nine 8-m-long polyethylene lateral lines, totaling 36 lateral lines on the entire bench. In each irrigation unit, three types of drippers were tested and their characteristics are shown in Table 1. These drippers were selected because they are the most used in the semi-arid region of Rio Grande do Norte state.

After the $400 \mathrm{~h}$ of operation of the four irrigation units with effluent, the step of emitter unclogging started, using the product MaxBio plus the enzymatic catalyst Byosol Swift, in the period from May 9 to 14, 2014.

The experiment was set in a completely randomized design, in a split-split-plot scheme. Plots corresponded to the doses of the biological products $\left(80,160,240\right.$ and $\left.320 \mathrm{mg} \mathrm{L}^{-1}\right)$, subplots to the applied treatments (T1, T2 and T3) and the sub-subplots to the types of drippers (D1, D2 and D3), with three replicates.

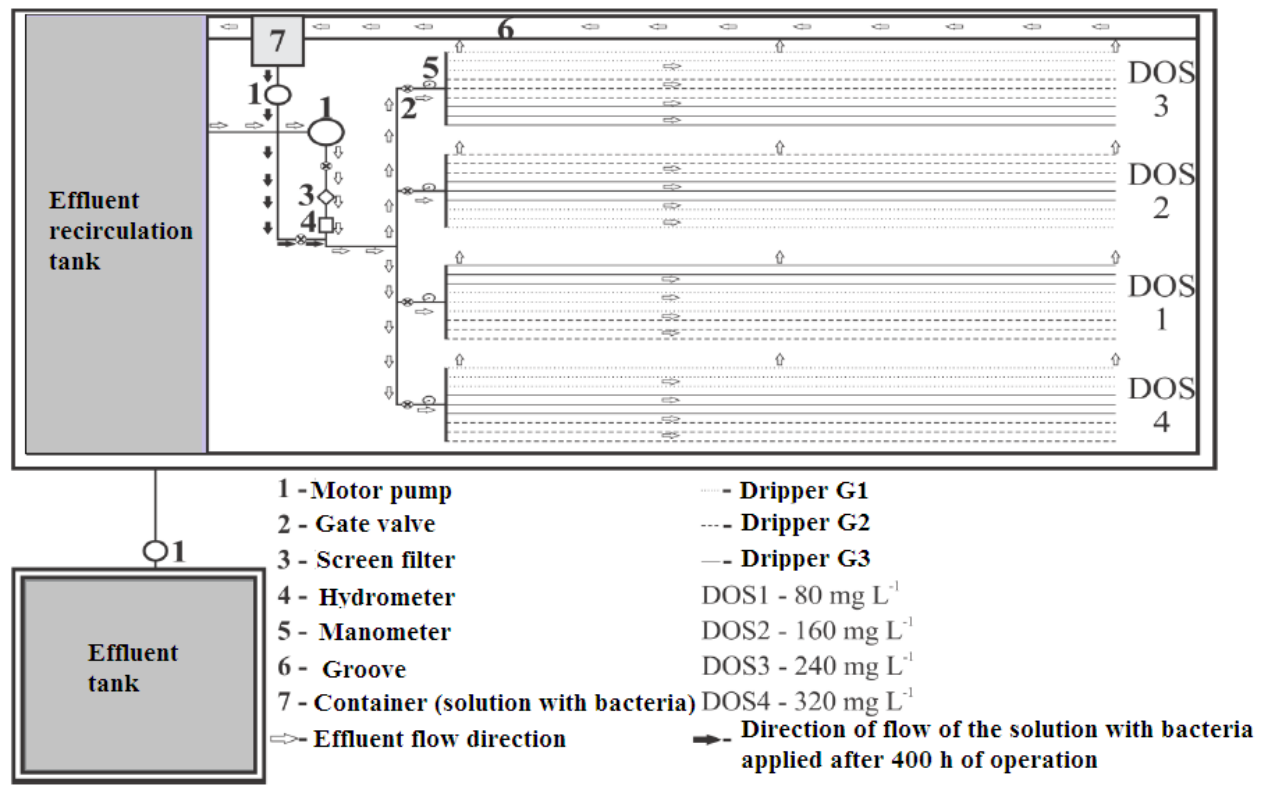

Observation: Reservoir received the effluent from the Effluent Treatment Station every 15 days and the tank for effluent recirculation

Figure 1. Scheme of the experimental bench 
Table 1. Drippers (D) used in the experimental tests with the respective manufacturer (M), pressure-compensating device (PD), nominal flow rate $(Q)$, flow rate coefficient $(k)$, exponent of flow rate characterizing the flowing regime $(\mathrm{x})$, filtering area $(\mathrm{A})$, labyrinth length $(\mathrm{L})$, coefficient of variation of manufacture $(\mathrm{CVm})$, recommended pressure range (P) and spacing between emitters (SE)

\begin{tabular}{|c|c|c|c|c|c|c|c|c|c|c|}
\hline D & M & $P^{*}$ & $\begin{array}{c}Q^{*} \\
\left(L^{-1}\right)\end{array}$ & $\mathbf{k}^{*}$ & $\mathbf{x}^{*}$ & $\underset{\left(\mathrm{mm}^{2}\right)}{\mathrm{A}}$ & $\underset{(\mathrm{mm})}{\mathrm{L}}$ & $\begin{array}{l}\mathrm{CV}_{\mathrm{m}}{ }^{*} \\
(\%)\end{array}$ & $\begin{array}{c}\mathrm{P}^{*} \\
(\mathrm{kPa})\end{array}$ & $\begin{array}{l}S E^{*} \\
(m)\end{array}$ \\
\hline D1 & Plastro Hydrodrip Super & No & 1.65 & 0.53 & 0.48 & $4.0^{* \star}$ & $37^{\star \star}$ & \pm 5 & $60-150$ & 0.30 \\
\hline $\mathrm{D} 2$ & Netafim Tiran & No & 2.00 & 0.69 & 0.46 & $70.0^{*}$ & $75^{\star}$ & \pm 7 & $100-300$ & 0.40 \\
\hline D3 & Netafim PCJ-CNJ\# & Yes & 2.00 & 2.00 & 0.00 & $2.0^{*}$ & $35^{\star}$ & \pm 7 & $50-400$ & 0.70 \\
\hline
\end{tabular}

and ${ }^{* *}$ - information obtained in the catalogs of the manufacturers and information measured with a digital caliper with precision of $0.01 \mathrm{~mm}$, respectively; ${ }^{*}$ - CNJ - anti-drain system

The doses of the product were prepared based on the following procedure: a) DOS1 - $80 \mathrm{mg} \mathrm{L}^{-1}$ resulting from the dilution of $2 \mathrm{~g}$ of concentrated powders of MaxBio and $100 \mathrm{~mL}$ of the enzymatic catalyst Byosol Swift in $25 \mathrm{~L}$ of freshwater; b) DOS2 - $160 \mathrm{mg} \mathrm{L}^{-1}$ resulting from the dilution of $4 \mathrm{~g}$ of concentrated powders of MaxBio and $100 \mathrm{~mL}$ of the enzymatic catalyst Byosol Swift in $25 \mathrm{~L}$ of freshwater; c) DOS3 - $240 \mathrm{mg}$ $\mathrm{L}^{-1}$ resulting from the dilution of $6 \mathrm{~g}$ of concentrated powders of MaxBio and $100 \mathrm{~mL}$ of the enzymatic catalyst Byosol Swift in $25 \mathrm{~L}$ of freshwater; d) DOS4 - $320 \mathrm{mg} \mathrm{L}^{-1}$ resulting from the dilution of $8 \mathrm{~g}$ of concentrated powders of MaxBio and $100 \mathrm{~mL}$ of the enzymatic catalyst Byosol Swift in $25 \mathrm{~L}$ of freshwater.

For each evaluated dose, two applications were performed with interval of two days between applications. The treatments corresponded to: a) T1 - without application of the product MaxBio + Byosol Swift; b) T2 - first application of the product MaxBio + Byosol Swift, with permanence time of $48 \mathrm{~h}$ inside lateral lines, and c) T3 - second application of the product MaxBio + Byosol Swift, with permanence time of $60 \mathrm{~h}$ inside lateral lines.

On May 9, 2014, the following procedure was performed for the first application of the products: a) the gate valve of the irrigation unit that received the dose DOS1 was completely open, while the valves of the others were closed; b) $80 \mathrm{mg} \mathrm{L}^{-1}$ of the solution were placed in a 62-L container and mixed in $25 \mathrm{~L}$ of water for $5 \mathrm{~min}$; c) then, the lateral lines were filled with the solution and the 0.5 -hp motor pump was activated; d) the procedure was the same for the other irrigation units that received the other doses (DOS2, DOS3 and DOS4) and e) the products remained at rest inside the lateral lines for $48 \mathrm{~h}$.

On May 11, 2014, the first evaluation of the system's hydraulic performance operating with treated domestic wastewater was performed in order to monitor the unclogging of the emitters. First, lateral lines were cleaned by opening the ends with the system in operation for $5 \mathrm{~min}$, in order to expel the degraded bio-incrustation. Then, all lateral lines were closed and the system operated for more $5 \mathrm{~min}$, in order to clean the emitters. Flow rate was determined by collecting the volume applied by the emitter using a $250-\mathrm{mL}$ graduated cylinder for $3 \mathrm{~min}$, at operating pressure of $100 \mathrm{kPa}$.

After evaluation, the second application of the products was performed following the same procedure of the first evaluation of hydraulic performance; however, the solution remained at rest inside the lateral lines for $60 \mathrm{~h}$ in order to compare and obtain the best permanence time of the products inside the lines. On May 14, 2014, the second evaluation of the system was performed according to the previous procedure.

The indicators of hydraulic performance used in the detection of levels of emitter unclogging in the irrigation units were: dripper flow rate $(\mathrm{Q})$ and relative flow rate reduction (RQR), described in Eqs. 1 and 2:

$$
\mathrm{Q}=\frac{\mathrm{V}}{1000 \cdot \mathrm{t}} \times 60
$$

where:

Q - dripper flow rate, $\mathrm{L} \mathrm{h}^{-1}$;

$\mathrm{V}$ - collected effluent volume, $\mathrm{mL}$; and,

$\mathrm{t}$ - time of effluent collection, min.

$$
\mathrm{RQR}=100\left(\frac{\mathrm{q}_{\mathrm{i}}-\mathrm{q}_{\mathrm{c}}}{\mathrm{q}_{\mathrm{i}}}\right)
$$

where:

RQR - relative flow rate reduction, \%;

$\mathrm{q}_{\mathrm{i}} \quad$ - initial flow rate, $\mathrm{L} \mathrm{h}^{-1}$; and,

$\mathrm{q}_{\mathrm{c}}$ - current flow rate, $\mathrm{L} \mathrm{h}^{-1}$.

The means were compared by Tukey test at 0.05 probability level. Simple and multiple regression models were selected based on the significance of the regression coefficients, applying the t-test at 0.05 probability level, on the coefficient of determination $(\geq 60 \%)$ and on the studied process.

\section{Results AND Discussion}

According to the analysis of variance, the interactions Doses of products, Applied treatments and Types of drippers (DOS x T x D) were not significant for the variables dripper flow rate $(\mathrm{Q})$ and relative flow rate reduction (RQR); however, there was effect only of the interactions T $x$ D and DOS $x$ D for the variables $Q$ and $R Q R$, respectively, as shown in Table 2

According to Table 3, there was statistical difference for the variable $\mathrm{Q}$ in the treatment $\mathrm{T} 1$, in relation to $\mathrm{T} 2$ and $\mathrm{T} 3$, for all types of drippers (D1, D2 and D3), while T2 and T3 did not differ statistically regarding the types of drippers.

Still analyzing the variable $Q$, there was statistical difference between the types of drippers for each one of the applied treatments due to the lower nominal flow rate of D1 compared with D2 and D3 (Table 1) and to the clogging caused by wastewater application; the highest levels of clogging occurred in the dripper D1.

As to the variable RQR (Table 3), the doses of the product MaxBio + Byosol Swift do not differ statistically for the studied types of drippers, while for the comparison between the types of drippers at each dose, there were: a) statistical difference between D1, D2 and D3 at the doses of 80 and $320 \mathrm{mg} \mathrm{L}^{-1}$; b) 
Table 2. Summary of the analysis of variance for the variables dripper flow rate $(\mathrm{Q})$ and relative flow rate reduction $(R Q R)$ in the split-split-plot scheme

\begin{tabular}{lccc}
\hline \multirow{2}{*}{ Source of variation } & $\begin{array}{c}\text { Degrees } \\
\text { of freedom }\end{array}$ & \multicolumn{2}{c}{ Mean square } \\
\cline { 3 - 4 } Doses of the products (DOS) & 3 & $0.028^{\text {ns }}$ & RQR \\
\hline Residue (a) & 6 & 0.027 & 92.98 \\
Applied treatments (T) & 2 & $0.81^{\text {ns }}$ & $2310.56^{* *}$ \\
DOS x T & 6 & $0.049^{\text {ns }}$ & $19.03^{\text {ns }}$ \\
Residue (b) & 16 & 0.011 & 32.31 \\
Types of drippers (D) & 2 & $5.10^{* *}$ & $4995.07^{* *}$ \\
DOS x D & 6 & $0.016^{\text {ns }}$ & $124.61^{*}$ \\
T x D & 4 & $0.059^{* *}$ & $128.61^{\text {ns }}$ \\
DOS x T x D & 12 & $0.0076^{\text {ns }}$ & $25.83^{\text {ns }}$ \\
Residue (c) & 50 & 0.016 & 52.77 \\
CV (\%) plot & & 10.47 & 60.72 \\
CV (\%) subplot & & 6.75 & 35.79 \\
CV (\%) sub-subplot & & 8.04 & 45.75 \\
\hline
\end{tabular}

** and * - Significant at 0.01 and 0.05 probability levels, respectively; ${ }^{\text {ns }}$ - Not significant at 0.05 probability level by $\mathrm{F}$ test

the drippers D2 and D3 were statistically different from D1 at the dose of $160 \mathrm{mg} \mathrm{L}^{-1}$ and c) the drippers D1 and D3 showed statistical difference in relation to D2 at the dose of $240 \mathrm{mg} \mathrm{L}^{-1}$.

In the study of Şahin et al. (2005), two applications of 500 $\mathrm{mL}$ of solution with Bacillus and Burkholdria, at the population level of $10^{9} \mathrm{CFU} \mathrm{mL} \mathrm{m}^{-1}$ inside the lateral lines, unclogged all drippers with biofilms and the flow rate reached maximum values after two weeks of biological treatment.

On the other hand, Resende et al. (2000) evaluated the efficiency of four doses of inorganic chlorine (150, 300, 450 and $600 \mathrm{mg} \mathrm{L}^{-1}$ ) in the chemical treatment of drippers with biological clogging. These authors obtained increase in mean flow rate for all tested types of emitters with the application of chlorine, except for the dripper Streamline, and evidenced, for the dripper Tiran, the highest response to the treatments. In addition, the dose of $300 \mathrm{mg} \mathrm{L}^{-1}$ was the most recommended.

Under experimental conditions different from those in the present study, Batista et al. (2012) tested four doses of free residual chlorine $\left(0.4,1.0\right.$ and $\left.1.9 \mathrm{mg} \mathrm{L}^{-1}\right)$ plus phosphoric acid, for the adjustment of $\mathrm{pH}$, in drip irrigation units that operated for $560 \mathrm{~h}$ with treated domestic wastewater. In this study, the dose of $0.4 \mathrm{mg} \mathrm{L}^{-1}$ was the most appropriate for the prevention of biofilm formation in drippers and lateral lines.

Under different experimental conditions, Ribeiro et al. (2008) evaluated the efficiency of using nitric acid (65\%) at $\mathrm{pH}$ 5.0 and sodium hypochlorite (12\%) to unclog drippers clogged by the use of waters with high content of material of biological origin and observed improvement in water distribution uniformity and reduction in the coefficient of variation of the drippers in all sectors.

The relationship between the variable $\mathrm{Q}$ and the doses of the products Byosol Swift and MaxBio for the combination D1 x T2 was best represented by the linear model, showing coefficient of determination $\left(\mathrm{R}^{2}\right)$ of 0.94 , while the $\mathrm{Q}$ values of the other combinations were not significantly altered by the doses of the products. Under different experimental conditions, Dehghanisanij et al. (2005) fitted equations of multiple linear regression between the population levels of phyto- and zooplankton and the flow rates of six types of drippers that applied treated domestic wastewater, and observed $\mathrm{R}^{2}$ values that ranged from 0.59 to 0.69 .

The relationship between the variable RQR and the doses of the product MaxBio + Byosol Swift for the combination 1 (D1 x T2) fitted best to the linear model, with coefficient of determination $\left(\mathrm{R}^{2}\right)$ equal to 1.00 . The relationship between the variable $R Q R$ and the doses of the product for the combination 2 (D2 x T2) was best represented by the square

Table 3. Means of dripper flow rate $(\mathrm{Q})$ and relative flow rate reduction $(\mathrm{RQR})$, in relation to the interaction of Applied treatments $x$ Types of drippers $(T \times D)$ and Doses of the product MaxBio + Byosol Swift $x$ Types of drippers (DOS x D)

\begin{tabular}{|c|c|c|c|c|c|c|c|c|}
\hline \multicolumn{4}{|c|}{$Q\left(L^{-1}\right)^{*}$} & \multicolumn{5}{|c|}{$\operatorname{RQR~(\% )~}$} \\
\hline \multirow{2}{*}{ D } & \multicolumn{3}{|c|}{$T$} & \multirow{2}{*}{ D } & \multicolumn{4}{|c|}{ DOS (mg L-1) } \\
\hline & T1 & T2 & T3 & & 80 & 160 & 240 & 320 \\
\hline D1 & $1.00 \mathrm{cC}$ & $1.13 \mathrm{bB}$ & $1.25 \mathrm{aB}$ & D1 & $34.89 \mathrm{aA}$ & $27.78 \mathrm{aA}$ & $23.78 \mathrm{aA}$ & $27.11 \mathrm{aA}$ \\
\hline D2 & $1.69 \mathrm{bA}$ & $1.85 \mathrm{aA}$ & $1.90 \mathrm{aA}$ & D2 & $2.33 \mathrm{aC}$ & $6.11 \mathrm{aB}$ & $7.67 \mathrm{aB}$ & $3.89 \mathrm{aC}$ \\
\hline D3 & $1.48 \mathrm{bB}$ & $1.85 \mathrm{aA}$ & $1.88 \mathrm{aA}$ & D3 & $15.33 \mathrm{aB}$ & $11.67 \mathrm{aB}$ & $16.56 \mathrm{aA}$ & $13.44 \mathrm{aB}$ \\
\hline
\end{tabular}

*Means followed by at least one equal letter, lowercase in rows and uppercase in columns, do not differ by Tukey test at 0.05 probability level

Table 4. Regression equations fitted to the variables flow rate $(\mathrm{Q})$ and relative flow rate reduction (RQR) as a function of doses (DOS) of the products Byosol Swift and MaxBio (80, 160, 240 and $\left.320 \mathrm{mg} \mathrm{L}^{-1}\right)$ in the drip irrigation units for the combination between types of drippers (D) and treatments (T2 and T3)

\begin{tabular}{|c|c|c|c|}
\hline Combinations & Specifications & Regression equations & $\mathbf{R}^{2}$ \\
\hline 1 & $\mathrm{D} 1 \times \mathrm{T} 2$ & $\widehat{\mathrm{Q}}=1.018+0.000538^{*} \mathrm{DOS}$ & 0.94 \\
\hline 2 & $\mathrm{D} 2 \times \mathrm{T} 2$ & $\widehat{\mathrm{Q}}=\overline{\mathrm{Q}}=1.851$ & - \\
\hline 3 & D3 x T2 & $\widehat{Q}=\bar{Q}=1.845$ & - \\
\hline 4 & D1 $\times$ T3 & $\widehat{\mathrm{Q}}=\overline{\mathrm{Q}}=1.253$ & - \\
\hline 5 & $\mathrm{D} 2 \times \mathrm{T} 3$ & $\widehat{\mathrm{Q}}=\overline{\bar{Q}}=1.896$ & - \\
\hline 6 & $\mathrm{D} 3 \times \mathrm{T} 3$ & $\widehat{\mathrm{Q}}=\overline{\mathrm{Q}}=1.880$ & - \\
\hline 1 & $\mathrm{D} 1 \times \mathrm{T} 2$ & $\mathrm{R} \widehat{\mathrm{Q}} \mathrm{R}=37.500-0.0458^{* *} \mathrm{DOS}$ & 1.00 \\
\hline 2 & $\mathrm{D} 2 \times \mathrm{T} 2$ & $\mathrm{R} \widehat{\mathrm{Q}} \mathrm{R}=-22.097+3.889^{*} \mathrm{DOS}^{0.5}-0.141^{*} \mathrm{DOS}$ & 0.99 \\
\hline 3 & $\mathrm{D} 3 \times \mathrm{T} 2$ & $\mathrm{R} \widehat{\mathrm{Q}} \mathrm{R}=\mathrm{R} \overline{\mathrm{Q}} \mathrm{R}=8.833$ & - \\
\hline 4 & D1 $x$ T3 & $R \widehat{Q} \mathrm{R}=\mathrm{R} \overline{\mathrm{Q}} \mathrm{R}=20.333$ & - \\
\hline 5 & $\mathrm{D} 2 \times \mathrm{T} 3$ & $\mathrm{R} \widehat{\mathrm{Q}} \mathrm{R}=-8.833+0.104^{*} \mathrm{DOS}-0.000234^{*} \mathrm{DOS}^{2}$ & 1.00 \\
\hline 6 & $\mathrm{D} 3 \times \mathrm{T} 3$ & $\mathrm{R} \widehat{\mathrm{Q}} \mathrm{R}=\mathrm{R} \overline{\mathrm{Q}} \mathrm{R}=7.167$ & - \\
\hline
\end{tabular}

** and * - Significant at 0.01 and 0.05 probability levels by t-test, respectively 
root model, with $\mathrm{R}^{2}$ of 0.99 . In combination 5 (D2 x T3), the relationship between the variable $R Q R$ and the doses of the product fitted best to the quadratic model, with $\mathrm{R}^{2}$ equal to 1.00. For the combinations 3 (D3 x T2), 4 (D1 x T3) and 6 (D3 $x$ T3), the mean was the best representation of the data. In the study conducted by Cararo et al. (2006) with treated domestic wastewater, there was a linear relationship between the data of clogging degree and operation time of the drip irrigation units, using filtration and chlorination $\left(0.5 \mathrm{~g} \mathrm{~m}^{-3}\right.$ of free residual chlorine at the end of each irrigation cycle).

\section{Conclusions}

1. There was significant effect of the treatments T2 $\left(1^{\circ}\right.$ application of the product) and T3 ( $2^{\circ}$ application of the product) on the recovery of the flow rate of the drippers.

2. For the reduction of relative flow rate, the doses of the product did not show statistical difference regarding the types of drippers.

\section{ACKnowledgments}

To the National Council for Scientific and Technological Development (CNPq), for the Research Productivity Grant Level 2.

\section{Literature Cited}

Batista, R. O.; Oliveira, R. A.; Santos, D. B. dos; Oliveira, A. F. M.; Azevedo, C. A. V. de; Medeiros, S. S. Obstrução e uniformidade de aplicação em sistemas de irrigação por gotejamento aplicandose efluente da suinocultura. Revista Brasileira de Engenharia Agrícola e Ambiental, v.17, p.698-705, 2013. http://dx.doi. org/10.1590/S1415-43662013000700002

Batista, R. O.; Santos, D. B.; Ferreira Neto, M.; Santos, W. O.; Barreto, H. B. F. Efficiency of chemical treatment on drip irrigation systems with sanitary sewage. Water Resources and Irrigation Management, v.1, p.25-29, 2012.

Batista, R. O.; Soares, A. A.; Moreira, D. A.; Feitosa, A. P.; Bezerra, J. M. Influência de diferentes qualidades de esgoto doméstico na vazão de gotejadores. Revista Caatinga, v.24, p.128-134, 2011.

Cararo, D. C.; Botrel, T. A.; Hills, D. J.; Leverenz, H. L. Analysis of clogging in drip emitters during wastewater irrigation. Applied Engineering in Agriculture, v.22, p.251-257, 2006. http://dx.doi. org/10.13031/2013.20286

Dazhuang, Y.; Zhihui, B.; Rowan, M.; Likun, G.; Shumei, R.; Peiling, Y. Biofilm structure and its influence on clogging in drip irrigation emitters distributing reclaimed wastewater. Journal of Environmental Sciences, v.21, p.834-841, 2009. http://dx.doi. org/10.1016/S1001-0742(08)62349-9

Dehghanisanij, H.; Yamamoto, T.; Ould Ahmad, B. V.; Fujiyama, H.; Miyamoto, K. The effect of chlorine on emitter clogging induced by algae and protozoa and the performance of drip irrigation. Transaction of the ASAE, v.48, p.519-527, 2005. http://dx.doi. org/10.13031/2013.18326

Eroglu, S.; Sahin, Ü.; Tunc, T.; Sahin, F. Bacterial application increased the flow rate of $\mathrm{CaCO}_{3}$-clogged emitters of drip irrigation system. Journal of Environmental Management, v.98, p.37-42, 2012. http:// dx.doi.org/10.1016/j.jenvman.2011.12.014
Hespanhol, I. Viabilidade de um $\operatorname{AVAD}\left(^{*}\right)$ não superior a 10-4 por pessoa por ano, para reuso agrícola de água, em países em desenvolvimento. Ambi-Água, v.4, p.124-134, 2009. http://dx.doi. org/10.4136/ambi-agua.92

Li, G.; Li, Y.; Xu, T.; Liu, Y.; Jin, H.; Yang, P.; Yan, D.; Ren, S.; Tian, Z. Effects of average velocity on the growth and surface topography of biofilms attached to the reclaimed wastewater drip irrigation system laterals. Irrigation Science, v.30, p.103-113, 2011. http:// dx.doi.org/10.1007/s00271-011-0266-4

Li, J.; Li, Y.; Zhang, H. Tomato yield and quality and emitter clogging as affected by chlorination schemes of drip irrigation systems applying sewage effluent. Journal of Integrative Agriculture. v.11, p.1744-1754, 2012. http://dx.doi.org/10.1016/S20953119(12)60179-8

Liu, H.; Huang, G. Laboratory experiment on drip emitter clogging with fresh water and treated sewage effluent. Agricultural Water Management, v.96, p.745-756, 2009. http://dx.doi.org/10.1016/j. agwat.2008.10.014

Puig-Bargués, J.; Arbat, G.; Elbana, M.; Duran-Ros, M.; Barragán, J.; Ramírez de Cartagena, F.; Lamm, F. R. Effect of flushing frequency on emitter clogging in microirrigation with effluents. Agricultural Water Management, v.97, p.883- 891, 2010. http:// dx.doi.org/10.1016/j.agwat.2010.01.019

Resende, R. S.; Coelho, R. D.; Piedade, S. M. S. Eficiência da cloração da água de irrigação no tratamento de gotejadores com entupimento de causa biológica. Revista Brasileira de Engenharia Agrícola e Ambiental, v.4, p.382-389, 2000. http://dx.doi.org/10.1590/S141543662000000300013

Ribeiro, T. A. P.; Paterniani, J. E. S.; Coletti, C. Chemical treatment to unclogg dripper irrigation systems due to biological problems. Scientia Agricola, v.65, p.1-9, 2008. http://dx.doi.org/10.1590/ S0103-90162008000100001

Rowan, M.; Mancl, K. M.; Tuovinen, O. H. Evaluation of drip irrigation emitters distributing primary and secondary wastewater effluents. Irrigation \& Drainage Systems Engineering, v.2, p.1-7, 2013.

Şahin, Ü.; Anapali, Ö.; Dönmez, M. F.; Şahin, F. Biological treatment of clogged emitters in a drip irrigation system. Journal of Environmental Management, v.76, p.338-341, 2005. http://dx.doi. org/10.1016/j.jenvman.2005.02.003

Silva, K. B.; Silva Júnior, M. J.; Batista, R. O.; Santos, D. B. dos; Barbosa Filho, S. Desempenho de gotejadores operando com efluente da castanha de caju sob distintas pressões de serviço. Revista Ceres, v.60, p.339-346, 2013. http://dx.doi.org/10.1590/S0034737X2013000300006

Souza, J. A. A.; Batista, R. O.; Ramos, M. M.; Soares, A. A. Contaminação microbiológica do perfil do solo com esgoto sanitário. Acta Scientiarum. Technology, v.33, p.5-8, 2011.

Yan, D.; Bai, Z.; Rowan, M.; Gu, L.; Shumei, R.; Yang, P. Biofilm structure and its influence on clogging in drip irrigation emitters distributing reclaimed wastewater. Journal of Environmental Sciences, v.21, p.834-841, 2009. http://dx.doi.org/10.1016/S10010742(08)62349-9

Yan, D.; Yang, P.; Rowan, M.; Ren, S.; Pitts, D. Biofilm accumulation and structure in the flow path of drip emitters using reclaimed wastewater. Transactions of the ASABE, v.53, p.751-758, 2010. http://dx.doi.org/10.13031/2013.30080 